\title{
KINERJA KEUANGAN DAN POTENSI KEBANGKRUTAN DARI PERUSAHAAN TRANSPORTASI PELAYARAN PADA TAHUN 2013-2017
}

\author{
Aditya Budi Kurniawan \\ Program Studi Magister Manajemen Universitas Tarumanagara \\ aditbudikuniawan@gmail.com \\ Carunia M. Firdausy \\ Program Studi Magister Manajemen Universitas Tarumanagara
}

\begin{abstract}
The purpose of this study is to analyze the financial performance and potential bankruptcy of shipping transportation companies listed in the Indonesia Stock Exchange in 2013-2017. the method to estimate financial performance and bankruptcy prediction is by using financial ratio \& Altman Z-Score method. The results show that the majority of companies indicating there is a signs of improving financial performance when commodity prices begin to recover. In addition to the analysis of the Altman Z-score bankruptcy Based on the Z-score value of the 14 sample companies, in 2013 there were 5 companies in the healthy category (z-score> 2.60), however in 2016 this number decreased to 3 companies . Whereas for companies that are in the grey area category (z-score 1.1-2.60) in 2013 there were 4 companies and then declined to the remaining 3 companies in 2016 . Whereas in 2013 company is in the category of financial distress $(\mathrm{z}$-score $<1,1)$ there are 5 companies and increased to 8 companies in 2016. In 2017 there was an increase in the companies in the healthy category \& grey area each into 4 companies. While companies in the financial distress category are reduced to 6 companies. This means there are improvements in 2017.
\end{abstract}

\begin{abstract}
Abstrak : Tujuan penelitian ini adalah menganalisa kinerja keuangan dan potensi kebangkrutan perusahaan transportasi pelayaran yang terdaftar di Bursa Efek Indonesia pada tahun 2013-2017. Metode untuk mengestimasi kinejra keuangan dan prediksi kebangkrutan menggunakan metode Rasio keuangan \&Altman Z-Score. Hasil analisa menunjukkan bahwa mayoritas perusahaan menunjukan tanda-tanda perbaikan kinerja keuangan pada saat harga komoditas mulai pulih. Selain itu pada analisa kebangkrutan Altman Z-score Berdasar nilai Z-score pada Dari 14 sampel perusahaan, pada tahun 2013 ada 5 perusahaan yang berada pada katagori sehat (z-score > 2,60), tetapi pada 2016 jumlah ini menurun hingga 3 perusahaan. Sedangkan untuk perusahaan yang berada pada katagori grey area (z-score 1,12,60) pada 2013 ada sebanyak 4 perusahaan, tetapi pada 2016 tersisa 3 perusahaan. Sedangkan perusahaan yang berada pada katagori financial distress (z-score <1,1) ada 5 perusahaan pada 2013 dan meningkat menjadi 8 perusahaan pada 2016. Pada tahun 2017 terjadi peningkatan perusahaan katagori sehat \& grey area masing-masing menjadi 4 perusahaan. Sedangkan perusahaan yang dalam katagori financial distress berkurang menjadi 6 perusahaan. Ini artinya ada perbaikan pada tahun 2017.
\end{abstract}

Keywords : Financial ratio, Du Pont, Almant and bankruptcy prediction.

\section{PENDAHULUAN}

Perubahan harga komoditas batubara dan minyak dunia dipastikan dapat memberikan dampak pada industri pelayaran di Indonesia. Indonesian National Shipowners Association (INSA) menyatakan bahwa berdasarkan informasi yang dihimpun dari para anggotanya, banyak kapal-kapal saat ini terpaksa diparkir karena tidak ada muatan, Khususnya Lebih dari 
3000 kapal jenis tug dan barge sebagai akibat turunnya harga kedua komoditas komoditas diatas.

Pasar utama angkutan batu bara dalam negeri adalah PT PLN, akan tetapi selama tahun 2015 ini, kemampuan BUMN listrik ini dalam menyerap batubara stagnant seiring tidak bertambahnya PLTU. Di sisi lain ekspor batubara semakin lesu karena permintaan terutama dari Tiongkok menurun. Di sektor minyak bumi khususnya offshore juga cenderung lesu akibat tidak adanya peningkatan produksi dari sumur baru minyak dan gas serta minimnya kegiatan eksplorasi maupun eksploitasi migas baru akibat harga minyak yang rendah. Produksi migas yang ada sekarang ini hanya mengoptimalkan sumur-sumur tua (beritasatu.com, 2015).

Berdasar hal diatas, penelitian mengenai keadaan industri transportasi pelayaran saat harga komoditas turun dan bangkit ditilik dari sudut pandang keuangan, penting dilakukan. Perubahan harga batubara dan minyak bumi tentu berpengaruh pada kinerja keuangan perusahaan tranportasi pelayaran yang terfatar di Bursa Efek Indonesia. Namun penelitian yang mengkaji kinerja keuangan perusahaan-perusahaan pelayaran yang terdaftar di Bursa Efek Indonesia belum banyak dilakukan. Kalaupun ada, data keuangan yang digunakan sebelum tahun 2013.

Metode yang digunakan untuk mengetahui kinerja keuangan adalah metode rasio keuangan dimana pada perhitungan ROA \& ROE menggunakan pendekatan Du Pont, sedangkan metode yang digunakan untuk mengetahui potensi kebangkrutan adalah metode Altman Z-score.

\section{TINJAUAN PUSTAKA}

Analisis laporan keuangan adalah aplikasi dari alat dan teknik analisis untuk laporan keuangan bertujuan umum dan data-data yang berkaitan untuk menghasilkan estimasi dan kesimpulan yang bermanfaat dalam analisis bisnis (Subramanyam, 2014, p. 4). Analisis rasio keuangan menurut Walsh (2003) adalah analisa terhadap rasio-rasio keuangan yang merupakan refleksi dari kondisi perusahaan yang dapat membantu manajer untuk menetapkan berbagai target serta standar perusahaan dan pengambilan keputusan strategi jangka panjang maupun pendek yang efektif.

Ada 5 jenis rasio keuangan yaitu, (1) rasio likuiditas yang digunakan untuk untuk mengetahui seberapa likuid perusahaan, sebuah bisnis secara keuangan disebut likuid apabila dapat membayar tagihan jangka pendek dengan tepat waktu (Titman, Keown \& Martin, 2011), (2) rasio profitabilitas digunakan untuk mengukur seberapa efisien perusahaan menggunakan asetnya dan seberapa efisien perusahaan menjalankan operasinya (Ross, Westerfeld \& Jaffe, 2013), (3) rasio solvabilitas digunakan untuk mengukur sejauh mana aktiva perusahaan didanai dari hutang. Artinya berapa besar beban utang yang ditanggung perusahaan dibandingkan dengan aktivanya (Kasmir, 2015), (4)rasio aktivitas digunakan untuk menilai kemampuan perusahaan dalam melaksanakan aktivitas sehari-hari atau kemampuan perusahaan dalam penjualan, penagihan piutang maupun pemanfaatan aktiva yang dimiliki (Munawir, 1988), (5) rasio pertumbuhan mengukur sebaik apa perusahaan mempertahankan posisi ekonomisnya di dalam industrinya (Weston dan Copeland, 1995).

Parameter di dalam mengukur rasio profitabilitas adalah Return on Assets (ROA) \& Return on Equity (ROE), Menurut Gibson (1995), komponen didalam perhitungan ROA dengan menggunakan metode Du Pont dibagi menjadi dua komponen rasio, yaitu Total Assets Turnover (TAT) dan Net Profit Margin (GPM), dimana kedua rasio ini saling behubungan dan memungkinkan untuk mengetahui lebih detil atas penyebab naik atau turunnya ROA. Menurut Titman, Keown \& Martin (2011) ada 3 komponen didalam perhitungan ROE dengan metode Du Pont, yaitu Total Assets Turnover (TAT) dan Net Profit Margin (NPM) atau sama seperti dalam menghitung ROA dengan metode Du Pont, namun 
bedanya ditambahkan komponen ketiga yaitu Financial Levergae atau Equity Multiplier. Dimana ketiga komponen ini memperlihatkan bagaimana semakin besar penggunaan hutang dapat memperbesar pengembalian atas ekuitas.

Model Altman (1968) dalam Munawir (2010) dapat digunakan untuk memprediksi kebangkrutan atau untuk mengetahui kondisi keuangan perusahaan di masa yang akan datang, dapat digunakan komponen rasio dalam rumus Z-Score sebagai alat prediksi terhadap kemungkinan bangkrut tidaknya suatu perusahaan. Model Altman dalam Prihadi (2010) menggunakan rasio - rasio sebagai berikut:

- Working Capital to Total Asset

Rasio Modal Kerja terhadap Total Aset digunakan sebagai alat diskriminan adalah rasio modal kerja terhadap total aset, rasio ini adalah ukuran bersih pada aset lancar perusahaan terhadap modal perusahaan. Perhitungannya adalah : X1=(Aktiva Lancar - Hutang Lancar)/(Total Aktiva).

- Retained Earnings to Total Assets

Rasio Laba yang Ditahan terhadap Total Aset merupakan ukuran dari profitabilitas kumulatif. Rasio ini dihitung dengan cara : X2=(Laba yang Ditahan)/(Total Aktiva).

- Earnings Before Interest and Taxes to Total Assets Rasio Laba sebelum Bunga dan Pajak terhadap Total Aset dihitung dangan membagi total aset perusahaan dengan penghasilan sebelum bunga dan potongan pajak dibagi dengan total aset dengan cara : X3=(EBIT)/(Total Aktiva).

- Market Value of Equity to Total Debt

Rasio Modal Sendiri terhadap Total Hutang menunjukan seberapa banyak aset perusahaan dapat menurun nilainya (diukur dari nilai pasar modal dilambah utang) sebelum liabilitas (utang) melebihi aset dan perusahaan menjadi bangkrut. Adapun perhitungannya adalah : X4=(nilai pasar ekuitas)/(Total Hutang).

$$
\text { Z-Score }=6,56 \mathrm{X} 1+3,26 \mathrm{X} 2+6,72 \mathrm{X} 3+1,05 \mathrm{X} 4
$$

\section{METODE PENELITIAN}

\section{Jenis Penelitian}

Jenus penelitian ini adalah penelitian deskriptif dengan menggunakan pendekatan kuantitatif, penelitian ini merumuskan dan menafsiran data yang ada sehingga memberikan gambaran yang jelas melalui pengumpulan data yang ada sehingga memberikan gambaran yang jelas melalui pengumpulan, menyusun dan menganalisis data sehingga dapat diketahui gambaran umum objek yang diteliti.

\section{Populasi dan Sampel Penelitian}

Populasi penelitian adalah perusahaan transportasi pelayaran yang sahamnya terdaftar dalam Bursa Efek Indonesia selama periode 2013 - 2017.

\section{Metode Pengumpulan Data}

Jenis data yang digunakan dalam penelitian ini adalah data sekunder berupa laporan keuangan yang dipublikasikan perusahaan transportasi pelayaran oleh idx.co.id.

\section{Variabel Penelitian}

Dalam penelitian ini variabel yang diamati adalah sebagai berikut :

Analisis rasio keuangan Merupakan salah satu alat untuk mengukur kinerja keuangan dalam periode tertentu untuk melihat kondisi keuangan pada masa lalu saat ini maupun masa yang 
akan datang. Jenis-jenis rasio keuangan yang digunakan untuk mengukur kinerja keuangan suatu perusahaan diantaranya :

Rasio likuiditas adalah suatu rasio untuk mengukur kemampuan perusahaan untuk memenuhi kewajiban finansial jangka pendek. Variabel rasio likuiditas diproksikan dengan menggunakan Current Ratio.

Rasio solvabilitas adalah suatu rasio untuk mengukur seberapa banyak perusahaan menggunakan dana dari utang (pinjaman). Variabel rasio solvabilitas diproksikan dengan menggunakan Debt to Total Equity Ratio, Debt to Total Assets Ratio \& Interest Coverage Ratio

Rasio profitabilitas adalah suatu rasio untuk mengukur aktivitas manajemen secara keseluruhan sebagaimana ditunjukkan dari keuntungan yang diperoleh dari penjualan dan investasi. Variabel rasio profitabilitas diproksikan dengan menggunakan Gross Profit Margin, Operating Profit Margin, Net Profit Margin, Return On Asset, dan Return On Equity.

Rasio pertumbuhan adalah suatu rasio untuk mengukur sebaik apa perusahaan mempertahankan posisi ekonomisnya di dalam industrinya. Variabel rasio pertumbuhan diproksikan dengan menggunakan rasio pertumbuhan penjualan dan rasio pertumbuhan laba bersih.

Kinerja keuangan perusahaan

Secara umum kinerja keuangan perusahaan merupakan gambaran tentang kondisi keuangan suatu perusahaan yang dinilai dengan alat-alat analisis keuangan, sehingga dapat diketahui dapat diketahui mengenai baik buruknya keadaan keuangan suatu perusahaan yang mencerminkan keberhasilan dalam mencapai tujuan perusahaan merupakan prestasi manajemen.

Analisa potensi kebangkrutan

untuk menganalisa potensi kembangkrutan penelitian ini menggunakan model Altman Z-Score dengan menghitung rasio keuangan yang telah dikombinasikan.

\section{Metode Analisa}

Dengan menggunakan metode rasio keuangan dan Altman Z-Score Menilai kinerja keuangan perusahaan \& prediksi kebangkrutan melalui data laporan keuangan perusahaan.

Melakukan Interpreasti desktiptif dari nilai hasil perhitungan rasio profitabilitas dengan parameter berupa Du Pont Return on Assets ratio, Du Pont Return on Equity ratio, Gross Profit Margin, Operating Profit Margin \& Net Profit Margin; rasio solvabilitas dengan parameter berupa Debt to Assets Ratio, Debt to Equity Ratio \& Interest Coverage Ratio; rasio likuiditas dengan parameter berupa Current Ratio; rasio pertumbuhan berupa parameter Sales Growth. 3. Melakukan Interpretasi deksriptif dari nilai hasil perhitungan model Altman ZScore sesuai dengan inteprestasi dari Prihadi (2010) yaitu:

- Z-Score diatas 2,60 : perusahaan tidak mengalami masalah dengan kondisi keuangan atau kategori sehat.

- Z-Score antara 1,10 - 2,60: perusahaan akan mengalami permasalahan keuangan jika tidak melakukan perbaikan yang berarti dalam manajemen maupun struktur keuangan atau kategori rawan (grey area).

- Z-Score dibawah 1,1 : perusahaan mengalami masalah keuangan yang serius atau kategori bangkrut (distress).

Berdasarkan hasil data yang diperoleh dari analisa data tersebut kemudian ditarik suatu kesimpulan.

\section{Teknik Analisa Data}

Dalam teknik analisis data, yang digunakan dalam penelitian ini adalah metode kuantitatif, yaitu analisis data yang menggunakan angka-angka ke dalam analisis rasio untuk 
membandingkan kinerja keuangan perusahaan satu dengan yang lain yang sejenis. Adapun oprasionalisasi dan formula dalam teknik analisa data dijabarkan pada Tabel.1

Tabel.1 Operasional Variabel

\begin{tabular}{|c|c|c|c|c|}
\hline No & VARIABEL & Teknik Analisa & PENGUKURAN & SKALA \\
\hline 1 & Return On Asset (ROA) & Rasio Du Pont & Net Profit Margin $\times$ Total Assets Turnover & Rasio \\
\hline 2 & Retun On Equity (ROE) & Rasio Du Pont & ROA X Equity Multiplier & Rasio \\
\hline 3 & Gross Profit Margin (GPM) & Rasio Profabilitas & $\frac{\text { Net Sales-COGS }}{\text { Net Sales }}$ & Persen \\
\hline 4 & Operating Profit Margin (OPM) & Rasio Profabilitas & $\frac{\text { Operating Income }}{\text { Net Sales }}$ & Persen \\
\hline 5 & Net Profit Margin (NPM) & Rasio Profabilitas & $\frac{\text { Net Income }}{\text { Net Sales }}$ & Persen \\
\hline 6 & Current Ratio (CR) & Rasio Likuiditas & $\begin{array}{c}\text { Current Assets } \\
\text { Current Liabilities }\end{array}$ & Rasio \\
\hline 7 & Debt To Assets Ratio (DAR) & Rasio Solvabilitas & $\frac{\text { Total Debt }}{\text { Total Assets }}$ & Rasio \\
\hline 8 & Debt To Equity Ratio (DER) & Rasio Solvabilitas & $\frac{\text { Total Debt }}{\text { Total Equity }}$ & Rasio \\
\hline 9 & Interest Coverage Ratio (ICR) & Rasio Solvabilitas & $\begin{array}{c}\text { Eearning Before Interest \& Tax (EBIT) } \\
\text { Interest Expense }\end{array}$ & Rasio \\
\hline 10 & Sales Growth & Rasio Pertumbuhan & $\frac{\text { Net Sales } t 1-\text { Net Sales to }}{\text { Net Sales to }}$ & Persen \\
\hline 11 & Net Income Growth & Rasio Pertumbuhan & $\frac{\text { Net Income t1 - Net Income to }}{\text { Net Income to }}$ & Persen \\
\hline 12 & Altmant Z Score & Prediksi Kebangkrutan Altman Z Score & $\begin{array}{l}\quad \text { Z Score }=6,56 \mathrm{X} 1+3,26 \mathrm{X} 2+6,72 \mathrm{X} 3+1,05 \mathrm{X} 4 \\
\text { Dimana : } \\
\mathrm{X} 1 \text { = Working Capital } / \text { Total Assets } \\
\mathrm{X} 2 \text { = Retained earnings/ Total Assets } \\
\mathrm{X} 3 \text { = Earning Before Interest and Tax / Total Assets } \\
\text { X4 = Market Value of Equity / total Liabilities } \\
\text { Apabila hasil kalkulasi Z Score : } \\
\text { Z Score > 2,60 = Aman } \\
1,1<\text { Z Score < 2,60 = Rawan Bangkrut } \\
\text { Z Score < } 1,1 \text { = Potensi Bangkrut tinggi }\end{array}$ & score \\
\hline
\end{tabular}

\section{HASIL DAN PEMBAHASAN}

\section{Analisa Kinerja Keuangan Dengan Metode Rasio Keuangan}

Secara keseluruhan semua perusahaan pelayaran transportasi mengalami indikasi pemulihan hampir pada pada semua indikantor pada tahun 2016 \& 2017 seiring membaiknya harga komoditas batubara \& minyak bumi. Yang paling terdampak dari pemulihan ini adalah rasio profitabilitas. Pada rasio solvabilitas yang paling terdampak adalah Interest Coverage Ratio. Pada Debt to Equity ratio cenderung datar dikarenakan selama tahun penurunan harga komoditas membuat sebagian besar perusahaan mencatat kerugian sehingga menggerus ekuitasnya meskipun sebenarnya jumlah nominal utang pinjaman juga menurun.

Dililihat dari jumlah perusahaan, tahun yang paling banyak mengalami penurunan adalah tahun 2016, karena saat itu harga komoditas minyak bumi mencapai titik terendah sedangkan pada jarga batubara mulai terakselerasi pada kuartal 3 2016. Pada 2017 saat harga komoditas semakin tinggi semakin banyak juga perusahaan pelayaran yang mengalami perbaikan.

Bila dibandingkan antara jumlah perusahaan yang mengalami perbaikan antara perusahaan transportasi pelayaran jenis angkutan batubara dengan jenis angkutan migas lebih banyak perusahaan pelayaran jenis angkutan batubara yang mengalami pemulihan.

Pada perusahaan transportasi pelayaran angkutan jenis lainnya cenderung tidak terlalu terpengaruh oleh kenaikan atau penurunan harga komoditas, tahun terburuk bagi perusahaan pelayaran jenis ini, terutama SMDR \& TMAS adalah tahun 2016 dimana tahun tersebut ekspor \& impor indonesia masih melemah 
Secara keseluruhan jumlah perusahaan yang mengalami pemulihan meningkat pada 2016 \& 2017, namun bias dibilang ini baru tanda pemulihan karena, rasio kinerja keuangan masih lebih rendah dibandingkan tahun 2013.

\section{Analisa Potensi kebangkrutan Dengan Menggunakan Metode Altman Z-score}

Secara keseluruhan jumlah perusahaan yang mengalami peningkatan Z-score meningkat pada 2016 \& 2017, itu artimya ada indikasi perushaan pelayaran kearah yang sehat. namun yang perlu digaris bawahi sebagian besar perusahaan transportasi pelayaran masih berada di bawah score 1,1 atau di dalam zona distress.

\section{PENUTUP}

\section{Kesimpulan}

Kinerja keuangan Perusahaan tranportasi pelayaran sangat dipengaruhi oleh naik turunnya harga komoditas batubara dan Migas, karena mayoritas perusahaan transportasi pelayaran yang terdaftar di Bursa Efek Indonesia adalah perusahaan pelayaran yang berperan sebagai pendukung di dalam industri tambang batubara dan migas. Sehingga bila harga kedua komoditas tersebut menurun, maka akan berdampak negatif bagi pertumbuhan penjualan dan profitabilitas perusahaan, begitupun sebaliknya apabila harga kedua komoditas meningkat maka akan memberi dampak positif pada pertumbuhan penjualan dan profitabilitas sehingga dampak turunanya dapat meningkatkan likuiditas perusahaan dan solvabilitas terutama pada kemampuan perusahaan membayar biaya bunga dari utang pinjaman. Hasil analisa menunjukan pada 2016 \& 2017 mayoritas perusahaan transporasi pelayaran menujukan tanda-tanda perbaikan, disebut tanda-tanda perbaikan karena kebanyakan rasio-rasio kinerja pada mayoritas perusahaan-perushaaan tersebut masih belum mencapai tingkat rasio pada tahun 2013 atau tahun-tahun sebelumnya.

Nilai Z-score Dari 14 sampel perusahaan pada tahun 2013 ada 5 perusahaan yang berada pada katagori sehat (z-score > 2,60), pada 2016 jumlah tersebut menurun hingga 3 perusahaan. Sedangkan untuk perusahaan yang berada pada katagori grey area (z-score 1,12,60 ) pada 2013 ada sebanyak 4 perusahaan lalu menurun hingga tersisa 3 perusahaan pada 2016 sedangkan Perusahaan yang berada pada katagori financial distress (z-score $<1,1)$ ada 5 perusahaan di 2013 dan meningkat menjadi 8 perusahaan pada 2016. Pada tahun 2017 terjadi peningkatan perusahaan katagori sehat \& grey area masing-masing menjadi 4 perusahaan. Sedangkan perusahaan yang dalam katagori financial distress berkurang menjadi 6 perusahaan. Ini artinya ada perbaikan pada tahun 2017 seiring membaiknya industri komoditas batubara dan migas

\section{Saran}

Bagi perusahaan \& pemilik modal, mengingat harga komoditas batubara \& migas memiliki pengaruh pada kinerja perusahaan, maka sebaiknya perusahaan dan pemilik modal yang berminat untuk masuk kedalam industri pelayaran, tidak hanya terfokus pada satu jenis komoditas saja, harus ada diversifikasi, untuk mengurangi dampak penurunan harga komoditas batubara \& migas. Selain itu sebaiknya perusahaan memiliki perjanjian jangka panjang menyangkut nilai kontrak dengan pemberi kerja, sehingga meskipun harga komoditas menurun, kinerja tetap stabil.

Bagi peneliti selanjutnya, tahun sampel yang digunakan hanya selama 2013 sampai 2017, dimana pada tahun 2016 kuartal ke 3 harga komoditas batubara \& migas baru pulih. Diharapkan kedepan tahun sampel yang digunakan bisa diperpanjang hingga setelah tahun 2017. Sehingga bisa lebih memperkuat gambaran pengaruh harga komoditas terhadap kinerja perusahaan tranportasi pelayaran. 


\section{DAFTAR PUSTAKA}

Ekonomi Melemah, Industri Pelayaran Terpuruk. (2015, 13 December). Beritasatu. Retrieved February 5, 2018 from http://www.beritasatu.com/ekonomi

Ikatan Akuntan Indonesia. 2015. Standar Akuntansi Keuangan; PSAK No.2. Salemba Empat. Jakarta.

Weston, J.fred., Copeland, Thomas E. (1995). Manajemen Keuangan (9 ${ }^{\text {th }}$ ed). Jakarta : Binarupa Aksara.

Kasmir. (2015). Analisis Laporan Keuangan, Edisi Pertama. Jakarta : Rajawali Pers.

Sadeli, Lili M. (2002), Dasar - Dasar Akuntansi. Jakarta : Bumi Aksara

Subramanyam, K. R. (2014). Financial Statement Analysis $\left(11^{\text {th }}\right.$ ed), New York, USA : Mcgraw-Hill.

Munawir, S. (1988). Analisis laporan Keuangan, Edisi ketiga. Yogyakarta: Liberty

Munawir, S. (2010). Analisis laporan Keuangan, Edisi keempat. Yogyakarta: Liberty

Prihadi, T. (2010). Analisis Laporan Keuangan. Jakarta: Ppm Manajemen

Gibson, Charles H. (1995). Financial Statement Analysis ( $6^{\text {th }}$ ed), Cincinnati, USA : SouthWestern College Publishing.

David, Fred R. 2009. Manajemen Strategis Konsep, Edisi 12. Jakarta: Salemba Empat

Ross, Stephen A., Westerfield, Randolph W., \& Jaffe, Jeffrey. (2013). Corpotate Finance (10th ed), New York, USA : McGraw-Hill

Titman, Sheridan., Keown, Arthur, J., Martin, John, D. (2011). Financial Management : Principles and Applications (11 $1^{\text {th }}$ ed), Boston, USA : Pearson.

Walsh, Ciaran. (2003). Key Management Ratios : Rasio-rasio Manajemen Penting Penggerak dan Pengendali Bisnis (3rd ed). Jakarta : Penerbit Erlangga.

Lesmana, Rico. (2003). Pedoman Menilai Kinerja Untuk Perusahaan Tbk, Yayasan, BUMN, BUMD, dan Organisasi Lainnya, Edisi Pertama. Jakarta: Elex Media Komputindo.

Darsono, \& Ashari. (2005). Pedoman Praktis Memahami Laporan Keuangan, Edisi Kesembilan. Jakarta : Penerbit Erlangga

Sugiyono. (2008). Metode Penelitian Kunatitatif Kualitatif dan $R \& D$. Bandung : Alfabeta

Ismaya, Sujana. (2006). Kamus Akuntansi. Bandung : Pustaka Grafika,

Janaloka, Yehezkiel T. (2016). Analisis Rasio Keuangan untuk menilai kinerja perusahaan telekomunikasi yang terdaftar di Bursa Efek Indonesia. Malang : Fakultas Ekonomi dan Bisnis. Universitas Brawijaya.

Ratnasari., Darminto., Handayani. (2014). Pengukuran Kinerja Keuangan Berdasarkan Analisis Rasio dan Ecpnomic Value Added (EVA) (Studi pada PT. Indofood Sukses Makmur, Tbk dan anak perusahaan yang terdaftar di Bursa Efek Indonesia 2009-2011). Malang : Fakultas Ilmu Administrasi. Universitas Brawijaya.

Lesmana, Theresia. (2013). Penilaian Kinerja Keuangan 5 Perusahaan Perbankan Terbesar Periode 2010-2012 menggunakan Du Pont System. Jakarta : Fakultas Ekonomi dan Komunikasi. Universitas Bina Nusantara.

Daulat \& Hildawati, (2014) Analisis Kinerja Keuangan Perusahaan Dengan Menggunakan Metode Du Pont System (Studi Pada Perusahaan Food \& Beverage yang terdaftar di BEI Periode Tahun 2008-2010). Jakarta : Fakultas Ekonomi. Universitas Esa Unggul.

Stefanie. (2015). Analisis Diskriminan Altman Z-Score Untuk Menilai Kinerja dan Memprediksi Kebangkrutan Pada Perusahaan Sub Sektor Telekomunikasi Di Indonesia. Jakarta : Fakultas Ekonomi dan Komunikasi. Universitas Bina Nusantara.

Peter \& Yoseph. (2011). Analisis Kebangkrutan dengan Metode Z-Score Altman, Springate dan Zmijewski Pada PT. Indofood Sukses Makmur Tbk Periode 2005-2009. Akurat Jurnal Ilmiah Akuntansi Nomor 04 Tahun ke-2 Januari-April 2011. 
